\title{
HEMINGWAY'S "THE SNOWS OF KILIMANJARO"
}

\author{
Maria Amelia Quelhas Moreira
}

\section{Summary}

Every writer has a place in space and time. Historical events and his own experiences will be reflected in one way or another, consci ously or unconsciously, in his work. This feature is specially noticea ble in the works of Hemingway. His books are an expression of the socie ty of his time and a reflection of most situations he has experienced in his life time. Hemingway used to say that he was mainly a reporter and as such he wrote his books. His books, written in the same direct and objective style of his reports, depict himself, his wives, his fami ly and his friends and all the experiences they have lived.

\begin{abstract}
Hemingway's own experiences on safari help to account for the origin of "The Snows of Kilimanjaro", which is going to be analysed in this article.The general outline of the story was almost certainly sug gested by Hemingway's own grave illness when he was on one of his expe ditions to Africa. The flight out of the plains country and the distant view of the enormous, snow-capped mountain of Kilimanjaro must have tou ched him deeply. During the flight east and no doubt also during a peri od of treatment in Nairobi, Hemingway had a lot of time to reflect on a topic which would naturally occur to him in such a situation: the death of a writer before his work is done.
\end{abstract}

When he came back to Europe he wrote his African stories. "The Snows of Kilimanjaro"was published in 1936 and it can be considered a masterpiece.

\section{INTRODUCTION}

We will start the analysis of the story, trying to show how action, point of view, setting, symbolism and characters contrive to present the central theme of the story: the guilt which derives from the consciousness of a work left undone. Harry's psychological conflict and death will constitute separate issues since they stand for the central theme of the story.

As an ultimate goal we will try to show that Harry, the dying writer, despite his life of dissipation and the waste of his talent, will prove to be Hemingway's typical hero: a courageous man who, despite the physical and moral sufferings he has to undergo, will not let himself fall a tragic victim of fate. He will overcome his misfortune in the end when death is marvellously negated by the brilliant dream of resurrection which is symbolized by the conquest of the summit of Kilimanjaro, the "House of God".

\section{GENERAL SUMMARY OF "THE SNOWS OF KILIMANJARO"}

Two people are waiting within sight of Kilimanjaro for the arrival of a plane to take them to civilization. The main character, Harry, a dissipated writer, has gangrene in his leg from a thorn scratch which he neglected. With him is Helen, his wife, whom he hates but whom he married for 
money. The price he paid for the money was the sacrifice of his talent as a writer.

Harry knows that he is dying and as he waits he recalls his war experiences where there had been a background of snow. Later he remembers Constantinople and the Bosphorus, Paris as it was in his writing days, women of all types, war and death, his grandfather's house, the Black Forest. He had meant to write it all down but instead he had married Helen and her money. As he grows weaker, he senses the approach of death, which seems to be symbolized by the passing of a hyena, more and more bold. Death comes closer until the dying man can feel its weight on his chest.

Then it seems to him that the plane arrives and he is taken aboard. The plane flies higher and higher until he realizes that it is taking him to the clean beauty of the snows of Kilimanjaro.

The hyena wakes Helen, who looks at her husband and sees that he is dead.

\section{HEMINGWAY'S LIFE AND HIS VISION OF THE WORLD}

Ernest Miller Hemingway, reporter, soldier, short story writer, novelist, playwright, deep-sea fisherman and big game hunter was born on July 21,1899 in Oak Park, Illinois.

His father was Dr Clarence Edmonds Hemingway, a physician who gave his son a woodman's training. Hemingway's early contact with nature taught him the love for nature which would follow him throughout his life and would be a constant presence in his stories.

His mother Grace Hall Hemingway was a religious woman but she was also very bossy and used to dominate her husband and children. In his later life Hemingway spoke of his mother as "an old bitch".

The conflict within his father- the manly life in the mountains, the proofs of courage and physical strength in contrast to the domesticated life he used to lead at home- touched Hemingway deeply and reflected upon his books. For Hemingway the mountains are the world of male companions and sport, of anti-civilization, simple and joyous as opposed to the plains which stand for the world of women, for "civilization" with all its moral complexity.

Hemingway's attitude towards women is a result of these opposing feelings. Women do not play an important role in his works. He is more comfortable in dealing with "men without women". Yet he feels an obligation to introduce women into his stories. Maybe as an over-reaction to his own mother, a dominating woman, many of his female characters are seen as a threat and destroyer of men. This happens to Helen, who, Harry says, "was a destroyer of his talent" (p. 60). Helen with her wealth has weaned her husband from all that sustained his virility. He calls Helen "a rich bitch" all the time, just as he used to call his mother. He depicts his women as bitches: this is the fate in Hemingway's imagination of most Anglo-Saxon women.

Ernest began writing articles for his high school newspaper. Most of his writings dealt with violent sports such as boxing and hunting. In 1917, soon after graduation, he was employed as a journalist. But what he wanted most at this time was to be part of the news, not just report it. This journalist training, however, was invaluable to him as a writer and observer of details.

When the First World War broke out he tried hard to enlist but was rejected because of a defective eye so he volunteered for ambulance duty in Italy. Far from having the glorious, patriotic experiences he had dreamed about, he found pain, panic and horror. Later he was wounded 
while trying to save one of the other wounded in the attack. He was considered a hero and recommended for the Italian medal of valour.

War had a profound significance on Hemingway's life. It affected everything he wrote. In his stories he usually shows that war leads to nothing but physical, emotional and material mutilation. But although war is self-destruction, misery, horror and death, Hemingway also shows the commitment of a man to fight for what he believes in, as he logically reasons when he refers to the Spanish Civil War. War and its consequence, specially death, is always depicted in his stories. In "The Snows of Kilimanjaro" there are some sequences of interior monologue where Hemingway links war and death to snow:

\section{"And it was snow they tramped along in until they died that winter." (p. 56)}

After the end of the war, Hemingway went to Paris where he worked as a correspondent for American newspapers and became identified with the "lost generation", a group of artists who went to Paris to find a new way to write. After the war these artists were embittered, disillusioned with what they felt were old-fashioned values and were seeking after a new writing style. They were influenced by Gertrude Stein and Hemingway was one of her greater admirers. Her insistence upon unadorned style and simple words turned out to be a characteristic of Hemingway's style. These artists reflected in their works the new knowledge of psychology, which was causing men to view the individual and his problems in a new light. They were particularly interested in Freud's theories concerning the underlying reasons for the emotions, reactions and behaviour of an individual. "The Snows of Kilimanjaro", for example, is an experiment in the psychology of a dying man.

Hemingway's entire life was filled with action. He served as a newspaper correspondent again in the Spanish Civil War and World War II. Out of his experience in the Spanish War, in which he became deeply involved, appeared "For Whom the Bells Toll". He also hunted big game in Africa and became an expert on bullfighting in Spain. Partially explaining his interest in the bull-ring, he shows his interest in the technique of writing, when he says, "I was trying to learn to write, commencing with the simplest things, and one of the simplest things and the most fundamental is violent death".

Hemingway's typical hero is a courageous man of action, who faces death stoically, with a certain nobility of spirit. Hemingway's hero is tough, stoical, suffering, exhibiting the kind of Hemingway courage that we have been taught to call "grace under pressure". That is Harry's attitude in "The Snows of Kilimanjaro". He knows he is about to die and he has to face death. First he becomes aggressive and even cruel to his wife but later he apologizes and stoically resigns himself to the fact that he must die.

Considering the relation men - God - immortality, we can see that, although Hemingway had once said he regretted not to be a good Catholic, his actions and his books seem to indicate that, in fact, for him man does not need a religion. For Hemingway, human beings are more concerned about their earthly world than about their spiritual world. Harry, despite the fact that he knows the end is near, has no thoughts of God. He sees death as something he can almost touch, something that starts by "resting its head on the foot of the cot and he could smell its breath". (p. 74) Then it moved "up on him" and "came a little closer ... so its weight was all upon his chest". (p. 75) Although death produces on him a feeling of repulsion, he faces it in 
cold blood and his only regret is not to have time to write about everything he had intended to.

Harry's attitude of almost complete indifference to death is very common in Hemingway's works because for him the "genuine man" knows that death is inevitable and should not be feared. Therefore, one should not struggle against death but against passivity, futility and routine. All these elements dive man into a kind of "spiritual death" which is endlessly worse than "physical death".

Hemingway went to Africa for the first time in 1932. He wanted to go there not just as a matter of curiosity about the dark continent but because he had started to develop a philosophy of heroism and it had to be tested in action. Since his childhood hunting trips with his father, Hemingway had developed an ambivalent attitude towards animals- an admiration for their courage or beauty ( except in the case of hyenas ) and at the same time a desire to destroy them. Years later Hemingway would make a comment about how he had felt a need to kill animals so as not to kill himself. For him, hunting was always a necessary adventure, perhaps a way of quieting his many fears and feeling of guilt.

Out of his experiences in Africa appeared "The Green Hills of Africa" and later on the two famous short stories: "The Snows of Kilimanjaro" and "The Short Happy Life of Francis Macomber".

Hemingway lived in Cuba for many years until the Castro Revolution in 1959. There he wrote "The Old Man and the Sea", published in 1952 which retrieved his reputation and was largely responsible for his being awarded the Nobel Prize in 1954.

On July 2, 1961 he committed suicide at his home in Idaho, just like his father had done many years before. He was a frail old man as a result of years of hard drinking and several accidents he had had during his life.

\section{HEMINGWAY'S STYLE}

Although Hemingway's philosophy of life has undoubtedly affected the work of other modern authors, it his artistry as a writer that wielded the greatest influence. Hemingway's way of writing is considered "the one intrinsic style our century has produced".

He mastered the "single effect", everything in his stories contributed to a single mood. He believed that the main problem in writing is setting down what you truly feel. To get this effect of absolute reality, he records the bare actions and thoughts of his characters like when Harry says, in "The Snows of Kilimanjaro", that he is aware that those birds of prey waiting around the camp are the first harbingers of his death: "Don't be silly. I'm dying now. Ask those bastards". (p. 53)

Another important part of Hemingway's technique is "dispassionate understatement". Using this technique Hemingway makes an objective physical description of the emotions the character is feeling, being able to choose "what the actual things were which produced the emotion which you experienced", to quote his own words. This is clearly evident when Harry describes his first foretaste of death:

"It came with a rush; not as a rush of water nor of wind; but of a sudden evil- smelling emptiness and the odd thing was that the hyena slipped lightly along the edge of it". (p. 64) 
Hemigway's descriptive details are at a minimum. The language has a bare simplicity in keeping with the characters. The plain words, colloquial phrases and simple sentences stimulate within the reader sensations like those felt by the characters.

\begin{abstract}
"He lay then and was quiet for a while and looked across the heat shimmer of the plain to the edge of the bush. There were a few Tommies that showed minute and white against the yellow and, far off, he saw a herd of zebra, white against the green of the bush. This was a pleasant camp under big trees against a hill, with good water, and close by, a nearly dry water hole where sand grouse flighted in the mornings." (p. 53/54)
\end{abstract}

Gertrude Stein taught Hemingway a respect for the word and he developed great skill in choosing the exact one for his specific purpose.

However, Hemingway was interested in developing themes as well as in reporting emotions. He aimed at a reality which would transcend the reality of the moment and become a symbol, a universal representation of the emotion. Hence, his language is often symbolic and gives a significance to the story that at first reading is unsuspected.

One can say that the central theme of most of his stories is violent death. In fact, death is a dominant feature in "The Snows of Kilimanjaro". His stories deal largely with the unpleasant aspects of life. Many of them emphasize the reactions of the characters to a world which is not too kind. Some deal with the discovery by young men of the cruelty of human beings like those which depict war time. Many are pessimistic because of Hemingway's loss of faith in usually accepted ideas, a characteristic of the "lost generation".

Partly because of the plain presentation of violence exactly as it occured and partly because of Hemingway's completely masculine prose, came the term "hard- boiled novel". Hemingway invented this new type. He also showed how effective in this genre could be understatement. By under- playing heroism, by reporting objectively without any subjective build- up, he forced the reader to compensate for the omission through using his own imagination.

\title{
GENERAL ANALYSIS OF "THE SNOWS OF KILIMANJARO"
}

Having set its background, we shall start analysing the short story "The Snows of Kilimanjaro" in terms of its action and point of view, Harry's psychological conflict, "death", setting, symbolism and characters.

\section{ACTION AND POINT OF VIEW}

"The Snows of Kilimanjaro" has little action in the sense of physical movement ( or plot ). The action is essentially in Harry's mind and the movement is the advance of death. Harry has three physical signs of the approach of death. Firstly he feels death as a rush, "not a rush of water or of wind; but of a sudden evil- smelling emptiness" (p. 64). Secondly death approaches with "a puff, as of a wind that makes a candle flicker and the flame go tall" (p. 67). Finally death is personified as Harry describes its approach: "... death had come and rested its head on the foot of the cot and he could smell its breath" (p. 74).

The story may well be described as a study of what happens in the mind of a person (Harry), 
dying and regretful, contrasted with the limited viewpoint of another ( Helen ) who does not feel or fear so much the coming death.

The narrative is presented in two levels: Harry's dialogues with Helen and his sreams of consciousness. The dialogues are interspersed with sequences of interior monologue where the main character, Harry, recall certain episodes from his youth and from his life before Helen. There is an omniscient narrator who presents everything which goes on in Harry's mind: his thoughts,
"So now it was all over, he thought. So now he would never have a chance to finish it. So this was the way it ended in a bickering over a drink. Since the gangrene started in his right leg he had no pain and with the pain the horror had gone and all he felt now was a great tiredness and anger that this was the end of it." (p. 54)

and his recollections of the past.
"He thought about alone in Constantinople that time, having quarrelled in Paris before he had gone out. He had whored the whole time and then, when that was over, and he had failed to kill his loneliness, but only made it worse, he had written her, the first one, the one who left him, a letter telling her how he had never been able to kill it ..." (p. 64)

Partially through the dialogues and partially through Harry's thoughts, we are shown how he perceives his situation both physically and morally and how he remembers his entire life. Harry's words and thoughts relating to the present, to his final hours with Helen and to his life with her, together with his final dream constitute the framework of the plot.

The sequences of interior monologue are moments of heightened consciousness which reveal all the things Harry should have written about, but never has. "There was so much to write." (p. 66 ), the dying writer realizes, and his last thoughts are moving recollections of some of the many things that will now go unwritten.

This consciousness that he is dying before his work is done represents Harry's psychological conflict which leads us to the central theme of the story: guilt.

\section{HARRY'S PSYCHOLOGICAL CONFLICT}

The death of a writer before his work is done was one of Hemingway's theme of reflection. This is mainly because the time available is so short and the temptations not to work are so strong. Harry, the dying writer, has succumbed to the temptation not to work and when he starts to be aware of the approach of death he begins to realize the true pain of death: not physical pain but that which results from guilt. He hopelessly remembers wasted time and all the material he had accumulated for writing but had put off using indefinitely, and which is now lost forever. He tries to rationalize away these painful thoughts about unfinished work by doubting whether he had ever had any real talent. 
knew enough to write them well. Well, he would not have to fail at trying to write them either. Maybe you could never write them, and that was why you put them off and delayed the starting. Well he would never know, now." (p. 54)

Physical death is honourable and he doesn't fear it. But as he dies physically he loses forever any chance to retrieve his work, to start writing again. He doesn't care that he is about to die but he can't accept the fact that his work will be left unwritten. So it is spiritual death that haunts him and not physical death. What makes him torture himself is not the knowledge of his approaching death but the consciousness of all the literary riches he hasn't written about and which will go with him underground. He had come from Paris on safari, not simply for a vacation but in search of a miracle to revitalize his abandoned career.
"Africa was where he had been happiest in the good time of his life, so he had come out here to start again. They had made this safari with a minimum of comfort. There was no hardship; but there was no luxury and he had thought that he could get back into training that way. That in some way he could work the fat off his soul the way a fighter went into the mountains to work and train in order to burn it out of his body."(p. 60)

Another obsession of Harry's is the deep sense of his loss of artistic integrity. Having given up his talent in favour of a luxurious way of life by marrying a rich woman and then growing into complete dependence on it, he had died artistically long before his physical death. He knows that he has traded his former integrity for "security and comfort", destroying his talent. So he accuses himself conscious that he is the only one responsible for the destruction of his talent by worshipping a false god: money and luxury.
"He had destroyed his talent by not using it, by betrayals of himself and what he believed in, by drinking so much that he blunted the edge of his perceptions, by laziness, by sloth and by snobbery, by pride, and by prejudice, by hook and by crook."
(p. 60)

Harry has traded himsef away when he married Helen for her money. He has neglected his talent so he has to pay a price and death is his share. He is guilty of literary blasphemy and he must be punished for his fatal greed, for his laziness, for pride and snobbery. But when death finally comes to claim him, it is negated by the brilliant dream of resurrection, as we are going to see later.

\section{DEATH}

Death is related to the central theme of the story: the death of a writer before his work is done, and the description of how it feels to die is probably the most original feature of "The Snows of Kilimanjaro".

Like Hemingway, Harry, the writer in the story, has been obsessed for years with curiosity about the idea of death. Now that it is close he has lost all curiosity about it, feeling only a "great tiredness and anger" over its inexorable approach. "For this that now is coming, he had very 
little curiosity. For years it had obsessed him; but now it meant nothing in itself." (p. 54)

The real sensations of death strike Harry three times: first, like a rush, not of water or wind, but of emptiness; second, like a puff of wind; third, like a weight upon his chest.

Certain perceptions accompany the approach of death: daylight fades into a dark night, afternoon heat is replaced by dreams of snow, conscious thoughts melt into fantasy and visions, vultures fly around the camp, a hyena wails.

Present from the beginning of the story is the odour of carrion due to the gangrene. It is an important sign of the approach of death.

Harry is a man of action, a hunter, but ironically he is dying because of a thorn scratch, merely taking pictures. Thus his death becomes a horrible mockery of life.This kind of death is considered to be a defeat for the one who dies, a consequence of his failure. At first Harry reacts with hostility and cynicism to the approach of death. He harasses Helen, deriving some bitter satisfaction from it. "If you have to go away", Helen complains, "is it absolutely necessary to kill off everything you leave behind?" (p. 58). By anger, his pride is asserted and he is able to hide his fears. Besides that he uses something more effective: evasion.

Alcohol is a way to evade reality but it is when he recalls his past life that Harry really compensates for actual desperation and death is temporarily forgotten. When he returns to the reality of the present, he is able to face fate, even with indifference: "Now he would not care for death." (p. 73). Harry can look bravely on all its face: a hyena, vultures. He even thinks that death is not there: "It went in pairs, on bicycles, and moved absolutely silently on the pavements." (p. 71). And in the end death is finally defeated when, in his last fantasy, he is taken to the top of Kilimanjaro, a promise of immortality.

\section{SETTING}

The setting of "The Snows of Kilimanjaro" is the final afternoon and evening in the life of a writer named Harry, dying of gangrene in a camp near the edge of the Tanganyika plains country.

The Tanganyika plains are situated in Africa, land of heat and light. This is the place Harry has chosen to find illumination for the darkness in his soul and inspirational warmth to melt his frozen talents. Ironically, Africa becomes his graveyard.

The most important element in the setting is the contrast between the mountain and the plains. The symbolism which entangles in the mountain and the plains prevails over a merely descriptive analysis of setting.

The ultimate landscape, of course, is that of Kilimanjaro, rising majestically far above the plains. It represents a synthesis of the story. It is a physical and ultimate sign that the world of purity, innocence and aspiration prevails over the world of corruption and misery.

Before he dies, Harry transcends the plains, the forests, the hills, even the clouds; it is then that he sees the top of Kilimanjaro in a moment of ecstasy. The world of the damned, the world where men worship money and comfort is symbolically abandoned at last; Harry discovers the "House of God"on the archetypal holy mountain. 
Hemingway uses several natural symbols. Two of them are very important symbols in the story and are introduced in the very beginning, in the epigraph: the mountain and the leopard.

Kilimanjaro is the mountain and its western summit is called the "House of God" by the Masai. There we can find "the dried and frozen carcass of a leopard." (p. 52). The mountains are symbolic of purity, innocence and aspiration in contrast to the misery and corruption of the plains. So the clean death of the overreaching leopard and the dirty painless death through gangrene are used as powerful symbols. The clean carcass of the leopard on the summit of the mountain contrast with the man rotting on the dusty plain. The animal having transcended the limits of nature, went courageously in search of the unknown heights, the absolute, the ideal; it died heroically. The man did not dare, achieved nothing, went nowhere, and died cursing the darkness. The beast signifies the artist that dies nobly, seeking the summit, and the gangrene stands for the corruption and mortification of the talent misused, prostituted, permitted to atrophy.

The leopard relates in another way, however. Like the animal that belonged to the plains- land of the fit and the fighters, land of reality and competition- Harry had a romantic weakness for the world of wealth. Attracted by dreams of "high life", he went too far out of his element and eventually found himself trapped, his talent and creativity frozen, dried up.

\section{"But, in yourself, you said that you would write about these people; about the very rich; that you were really not of them but a spy in their country; that you would leave it and write of it and for once it would be written by some one who knew what he was writing of. But he would never do it, because each day of not writing, of comfort, of being that which he despised, dulled his ability and softened his will to work so that, finally, he did no work at all." (p. 59/60)}

In the social climbing of his personal Kilimanjaro, Harry, like the leopard, actually destroyed himself by straying where he did not belong, "by betrayals of himself and what he believed in,...". (p. 60)

In the final dream of escape, Harry dreams that the rescue plane has finally showed up but, instead of taking him to a hospital, he understands that his real destination is "the square top of Kilimanjaro" (p. 76). In his moment of death he finally conquers the mountain ( the "House of God" ) "wide as all the world, great, high and unbelievably white in the sun." (p. 76). Though there is no hope of regeneration, Harry faces his failure without self- pity, with understanding, submission to destiny, having at last burned "the fat off his soul" (p. 60). So we can also say that his reaching the mountain in his final fantasy symbolizes a promise of resurrection and immortality.

But back to earth the denouement of the story shows Harry's wife, Helen, walking in the middle of the night down on the plains far from the Kilimanjaro and calling to a husband who does not answer.

Helen is a woman, a symbol of danger and threat. She represents the wealth that has corrupted Harry, with all the comfort, security it could buy, and that ultimately destroyed him. Women and money are nothing but instruments and agents: they coexist to help the writer in his moral selfdestruction. So Helen is a death symbol, the symbol of his destruction. He calls her "rich bitch" and refers to her money as "bloody money" or "damned money". 
Being a death symbol, Helen is closedly linked to the vultures and the hyena, animals which feed on carrion. It is natural that Harry, whose flesh is rotting (in fact, carrion already) should associate these creatures with the idea of dying. As he lies near death in the mimosa shade at the opening of the story, he watches the vultures obscenely squatting in the glare of the plain. As night falls and the voice of the hyena is heard in the land, the death image transfers itself from the vultures to this foul devourer of the dead. With the arrival of his first, strong premonition of death, which has no other form than "a sudden, evil- smelling emptiness" (p. 64), Harry finds that "the odd thing was that the hyena slipped lightly along the edge of it" (p. 64). And in his last moments it is the image of a hyena again that appears to him as a final sign of the approaching death. Harry tells his wife:

\section{"Never believe any of that about a scythe and a skull ... it can have a wide snout like a hyena." (p. 74).}

The usual symbols of death, the scythe and the skull, are rejected in favour of the foul and obscene creatures which have now come to dominate Harry's imagination.

The hyena is also used to foreshadow Harry's death. Its presence is felt nearer and nearer. First "a hyena crossed the open on his way around the hill" (p. 63). When Harry foretastes his death for the first time "the hyena slipped lightly along the edge of it" (p. 64), referring to the emptiness that he associates the sign of death with. Just before he felt death for the third and last time "he heard the hyena make a noise just outside the range of the fire." (p. 74), as a last sign that death is about to reach out for him. At last "death had come and rested its head on the foot of the cot and he could smell its breath." (p. 74). And in his thoughts he curses this final image of death: "You've got a hell of a breath, ... You stinking bastard." (p. 74).

Another important symbolic device is alcohol. Alcohol has an ambivalent significance in the story. It is essential to moments of celebration. It reminds Harry of a time in Paris when he was very poor and lived among the poor but was free and able to write. Those were days of goodwill, friendship and accomplishment. On vacation in the Alps, Harry and his friends sought out the taverns for music "and the cherry- pit taste of good Kirsch" (p. 57). Harry and Helen share a whiskey and soda as a sign of their reconciliation.

On the other hand, alcohol can function as a pain- killer. Harry, while lying on his death- bed, insists on having a drink. At this moment alcohol is a form of escape, a means to relaxing from the tension which results from his struggle against the coming death. Besides alcohol also helps to ease the pain.

When Harry recalls the places of his youth, he thinks of those people in Paris who used to hide from the reality of poverty in their own drunken worlds, sleeping along street gutters. But when he was poor, young and free he didn't use to drink. Now that "he had traded away what remained of his old life ... for security, for comfort, too," (p. 62), he is also a prisoner of alcohol. It had become a drug to his conscience during his marriage to Helen. Ironically Helen had made use of alcohol after deaths in her family but she was saved from alcoholism by her marriage to Harry.

Therefore alcohol symbolizes self- destruction for Harry, while for Helen it was a threat she managed to overcome. 
Harry, the writer, and his wife Helen are the main characters in "The Snows of Kilimanjaro".

Harry is an ambiguous, complex and round character and he will only be totally revealed at the end of the story.

We face two different Harrys throughout the story: the disillusioned man who is near death and has to cope with his guilt and the "other Harry", adventurous, vital, self- reliant, who seems to have been part of the action wherever he could find it.

Harry's dialogues with Helen, specially at the beginning of the story, reveals the first Harry: a man who is extremely irritated. He knows the end is near and inevitable feelings of loss and defeat make him suffer. To make up for all his sufferings, Harry puts the blame on Helen. He becomes sarcastic, aggressive and even cruel as he attempts to convince them both that the fault was Helen's money. He says: "you can take the leg off and that might stop it, though I doubt it. Or you can shoot me. You're a good shot now. I taught you to shoot, didn't I?" (p. 53)

He sarcastically apologizes for his evil-smelling leg and then he says he has always faked his love for her.

\section{"Don't you love me?" Helen asks. \\ "No." said the man. "I don't think so. I never have." (p. 55)}

He calls her a "bitch" all the time and even execrates the notion of love. "Love is dunghill", says Harry, "And I'm the cock that gets on it to crow." (p. 58). Afterwards he apologizes and says "I've never loved anyone else the way I love you." (p. 58). Saying that he loves her relaxes him from his guilt, in a certain way.

Little by little Harry's hostility is abandoned. He stoically resigns himself to the fact that he must die. It is then, by means of interior monologue, that emerges another Harry, perhaps the real one: ashamed, afraid, with a desperate need to understand himself and justify or compensate for his present situation.

He then realizes how wrong it was to make a escapegoat out of Helen.

\section{"Why should he blame this woman because she kept him well? He had destroyed his talent ..." (p. 60)}

He tries to evade reality, dreaming of the past. He dreams of moments of courage and joy that could have been good ideas for his books. On the other hand, he also dreams of moments of horror and tragedy in war time.

But suddenly comes his final dream. He reaches the summit of Kilimanjaro, leaving his failures and personal ruin behind on the plains.

Helen, as seen by her husband, is presented mostly in a negative perspective. She is a death symbol for him. Harry considers that his wife's wealth has deprived him of life far more than gangrene will. Helen and her money are for him agents of destruction, like the vultures and the hyena.

When Harry speaks to her, he calls her a silly fool, a bore, a bitch but he admits that she remains 
physically interesting and desirable.

"She was still a good- looking woman, she had a pleasant body ... she was not pretty, but he liked her face ..." and he says that "she had a great talent and appreciation for the bed." (p. 61)

Helen is a flat character as she does not change throughout the story.

Psychologically "she had been acutely frightened of being alone." (p. 62) but as she marries Harry she "had built herself a new life" while "he had traded away what remained of his old life" (p. 62) in a reference that Helen is a symbol of his destruction and the corruption of his talent.

Another image of Helen presented in the story contrasts with the one given by Harry. Ironically, while she is for him a death symbol, she appears by her words and actions to be a positive illustration of life. She is presented as a maternal figure: she struggles to make him comfortable, she proposes reading to him, worries about his rest, has broth made from meat she herself shoots.

Helen gives Harry moral encouragement. She says: "You can't die if you don't give up." (p. 53). She keeps on telling him that the rescue plane will soon arrive and remarks that the vultures and the hyena are common nuisance at any African camp site and not harbingers of his death.

However Helen blames Africa for what it has done to her husband. She says:

"I wish we'd never come here."

"... we could have gone shooting in Hungary and been comfortable." (p. 55)

And she asks in dismay: "What have we done to have that happen to us?" (p. 55)

In contrast to the character of Harry, Helen is a person who dislikes looking for the hidden dimensions of people and things and has little interest in dreaming of the past or fearing the future. This deep contrast between Helen and Harry stresses their basic inability to communicate with each other.

\section{CONCLUSION}

We have tried to show in this article how much the knowledge of an author's historical and social context, his vision of the world and his style contributes to the understanding of his work. This background knowledge was invaluable to the development of this analysis.

We hope to have presented the evolution of Harry's psychological conflict: from his awareness of the approaching death, bringing up feelings of failure and waste, to his stoical submission to his terrible fate and up to his final overwhelming victory over death, when he marvellously reaches the summit of Kilimanjaro, the holy mountain, leaving his fate behind on the plains. Hence, achieving immortality.

As it is stated in the last paragraph of "Ernest Hemingway and his World":

"The Hemingway code of courage, the Hemingway hero and his stoic holding on against odds, have exerted an influence beyond literature. He reminds us that to engage literature one has first 


\section{BIBLIOGRAPHICAL REFERENCES}

1- BAKER, Carlos. The two African stories. In: WEEKS, Robert P. Hemingway: a collection of critical essays. New York: PrenticeHall, 1962. p. $72-85$

2- BURGESS, Anthony. Ernest Hemingway and his world. New York: Charles Scribner's Sons, 1985. 128 p.

3- FIEDLER, Leslie. Men without women. In: WEEKS, Robert P. Hemingway: a collection of critical essays. New York: PrenticeHall, 1962 p. 86- 92

4- HALLIDAY. E. M. Hemingway's ambiguity: symbolism and irony. In: WEEKS, Robert P. Hemingway: a collection of critical essays. New york: Prentice- Hall, 1962. p. 52- 71

5- HEMINGWAY, Ernest. The Snows of Kilimanjaro. Penguin Books, 1970

6- Notes on the African stories- Ernest Hemingway. Longman York Press.

7- POOLEY, Robert C. The United States in literature. New York: America Reads, 1968.

8- TEIXEIRA, Anna Helena Van Wilpe. O conceito do homem segundo Ernest Hemingway. In: UNILETRAS, N. 2, p. 65- 76, Dez 1980, Ponta Grossa: UEPG 